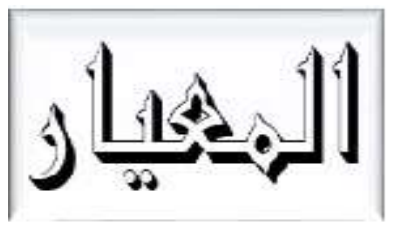

Al Mi'yar

Vol. 4, No. 1, April 2021

P-ISSN: 2620-6749, E-ISSN: 2620-6536

DOI: $10.35931 / a m . v 4 i 1.437$

\title{
PENGEMBANGAN BAHAN AJAR BAHASA ARAB BERBASIS KEARIFAN LOKAL BREBES
}

\author{
Umi Chabibatus Zahro', Ujang Khiyarusoleh² \\ 1Universitas Peradaban, Brebes, 2SMA Diponegoro 1, Purwokerto \\ Email: ${ }^{1}$ umicha.sy@gmail.com, ${ }^{2}$ ujang606bk@gmail.com
}

\begin{abstract}
This study aims to answer the needs of Arabic teaching materials for students of the University of Civilization which are included in the curriculum, Arabic teaching materials developed based on local wisdom of Brebes district, namely Kaligua tea garden agro-tourism and Pakujati and Buaran hot springs. According to Borg and Gall, the research and development method used, it's just that in this stage the researchers only got to the product validation and revision 1 stages, due to the COVID-19 pandemic period. The results of the existing research, obtained data that the Arabic teaching materials based on Brebes local wisdom are appropriate from the geographical location of Brebes district, this can be seen from the sub-topic of teaching materials, namely Kaligua tea gardens and Pakujati and Buaran hot springs. The next results can be seen from the evaluation of the material and design expert validator. For the results of the material expert validator of 78.8, it is said to be quite valid, it can be used but needs revision. Furthermore, the results of the design validator 78.5 are said to be quite valid, can be used but need revision. The next suggestion from the validator is that there is a need for additional further material to be developed according to local wisdom of Brebes Regency such as Malahayu reservoir, Mangroove forest, Penjalin reservoir.
\end{abstract} Keywords: Development, Teaching Materials, Arabic, Local Wisdom, Brebes

\section{PENDAHULUAN}

Pembelajaran bahasa Arab di perguruan tinggi merupakan sesuatu hal yang tidak asing lagi, dengan melihat beberapa kasus di Universitas Peradaban bahwa notabene mahasisswa merupakan mahasiswa yang pernah mempelajari bahasa Arab sebelum memasuki perguruan tinggi, akan tetapi penilaian hasil perkuliahan mahasiawa belum mencapai standar yang diharapkan oleh perguruan tinggi. Hal ini merupakan tantangan bagi dosen 
Umi Chabibatus Zahro \& Ujang K: Pengembangan Bahan Ajar Bahasa Arab Berbasis Kearifan Lokal Brebes

untuk melakukan hal yang lebih baik lagi dalam proses perkuliahan, seperti contoh yakni memberikan materi maupun menggunakan media pembelajaran sesuai dengan keadaan mahasiswa, agar materi perkuliahan dapat sesuai yang diharapkan.

Berdasarkan hasil observasi pada mahasiswa Universitas Peradaban saat perkuliahan bahasa Arab, ditemukan diantaranya: 1) rendahnya motivasi mahasiswa pada mata kuliah bahasa Arab, 2) rendahnya pemahaman dan pengetahuan terhadap mata kuliah bahasa Arab, 3) belum ada buku ajar mata kuliah bahasa Arab sebagai bahan tambahan rujukan perkuliahan.

Solusi terhadap permasalahan yang telah disebutkan di atas adalah menggunakan bahan ajar berbasis kearifan lokal, hal ini menekankan pada materi atau kosa kata bahasa Arab yang terdapat di dalam buku ajar itu sesuai dengan kehidupan daerah setempat yaitu kabupaten Brebes. Selain itu, mahasiswa akan mudah mengingat materi yang telah dipelajarinya.

Dalam pembelajaran bahasa Arab, ada beberapa metode pengajaran bahasa, diantaranya metode komunikatif. Dalam metode komunikatif ada kompetensi komunikatif seperti halnya versi kitab Al-Arobiyah Baina Yadaika, yang bertujuan agar mempelajari bahasa Arab dapat memiliki kompetensi kebahasaan, kompetensi komunikatif, dan kompetensi

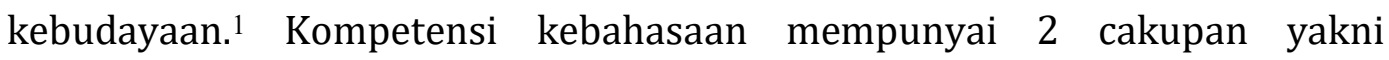
kemahiran 4 maharah (al-istimā', al-kalām, al-Qirāàh, dan al-kitābah) dan penguasaan unsur-unsur bahasa (al-așwāt, al-mufradàt, dan at-Tarkīb annahwiyyah). Kompetensi komunikatif merupakan kemamapuan berkomunikasi dengan penutur asli baik secara lisan maupun tulis, pembelajar mampu mengekspresikan dirinya secara baik. Selanjutnya kompetensi kebudayaan, yakni kemampuan memahami budaya bahasa.

Bahan Ajar merupakan seperangkat sarana yang memuat materi, metode, batasan dan evaluasi pembelajaran secara sistematis dan menarik sesuai dengan tujuan pembelajaran itu sendiri. ${ }^{2}$ Khosois al maddah at ta'limiyyah ada 5, yaitu: 1) self instructional yang berarti bahan ajar yang

\footnotetext{
${ }^{1}$ Ahmad Fuad Effendy. Metodologi Pengajaran Bahasa Arab (Malang: Misykat, 2012), 6575

2 Ika Lestari, Pengembangan Bahan Ajar Berbasis Kompetensi (Padang: Akademia, 2013), $1-3$
} 
Umi Chabibatus Zahro \& Ujang K: Pengembangan Bahan Ajar Bahasa Arab Berbasis Kearifan Lokal Brebes

mampu membuat mahasiswa belajar secara mandiri. 2) self contained berarti seluruh materi bersifat utuh. 3) stand alone yaitu bahan ajar yang dikembangkan tidak tergantung pada bahan ajar lain. 4) adaptive yaitu bahan ajar yang dapat menyesuaikan dengan perkembangan teknologi. 5) user friendly yaitu bahan ajar yang unsur instruksinya bersifat membantu dan bersahabat dengan pemakainya.

Fungsi bahan ajar mempunyai banyak aspek, diantaranya bagi guru yaitu untuk mengarahkan proses pembelajaran dengan baik dan terukur. Bahan ajar juga merupakan alat evaluasi dalam pencapaian pembelajaran. Jadi untuk bahan ajar yang baik jika pembuatan bahan ajar itu menggunakan kaidah yang tepat, maka guru akan mudah mengarahkan kegiatan pembelajaran dimulai dari kompetensi-kompetensi yang harus dikuasai oleh pembelajar itu sendiri. ${ }^{3}$ Sejalan dengan Ika, Sitepu berpendapat bahwa fungsi buku/ bahan ajar mengandung informasi tentang perasaan , pikiran, gagasan, atau pengetahuan untuk disampaikan kepada si pembaca. ${ }^{4}$ Sitepu menambahkan bahwa buku/ bahan ajar dipergunakan sebagai bahan membuat desain pembelajaran, mempersiapkan referensi lain, mengembangkan bahan belajar yang kontekstual, memberikan tugas, dan Menyusun evaluasi. Evaluasi dalam bahan ajar merupakan hal yang penting dikarenakan kegiatan ini adalah pertimbangan dalam mengambil keputusan. Seperti yang diutarakan Asrori dkk bahwa definisi evaluasi itu suatu proses yang sistematis dalam mengumpulkan, menganalisis dan menafsirkan data untuk penentuan hasil pembelajaran yang ditinjau dari tujuan/ indikator pembelajaran. ${ }^{5}$

Kearifan Lokal yang digaungkan oleh peneliti dalam membuat bahan ajar merupakan suatu hal yang baru dalam dunia bahasa Arab. Kearifan lokal ialah kebijaksanaan dalam budaya masyrakat, baik itu perilaku, adat, lagu, maupun tempat keramat. Sedangkan menurut kamus besar bahasa Indonesia (KBBI) kearifan ${ }^{6}$ berarti kebijaksanaan/ kecendekiaan, dan local berarti ruang yang luas/ suatu tempat. Jadi yang dimaksud dalam kearifan lokal adalah kebijaksanaan dalam pengetahuan dan budaya suatu tempat tersebut.

\footnotetext{
${ }^{3}$ Ika Lestari, Pengembangan Bahan Ajar Berbasis Kompetensi (Padang: Akademia, 2013), 7

${ }^{4}$ Sitepu. Penulisan Buku Teks Pelajaran (Bandung: Remaja Rosdakarya, 2012), 20-21

${ }^{5}$ Imam Asrori, dkk. Evaluasi Pembelajaran Bahasa arab (Malang: Misykat, 2012), 3

${ }^{6}$ Kamus Besar Bahasa Indonesia
} 
Umi Chabibatus Zahro \& Ujang K: Pengembangan Bahan Ajar Bahasa Arab Berbasis Kearifan Lokal Brebes

Sedangkan dalam penelitian ini maksud dari kearifan local itu sesuatu apa saja yang terkait dengan pengetahuan, adat istiadat, budaya, tempat/lokasi, keadaan atau kondisi alam di kabupaten Brebes.

Kearifan lokal (Local Wisdom) merupakan kecendikiaan terhadap kekayaan setempat/suatu daerah berupa pengetahuan, kepercayaan, norma, adat istiadat, kebudayaan, wawasan yang merupakan warisan dan dipertahankan sebagai sebuah identitas dan pedoman dalam mengajarkan kita untuk bertindak secara tepat dalam kehidupan, Sumarmi dan Amiruddin menjelaskan bahwa kearifan lokal merupakan pengetahuan lokal yang digunakan oleh masyarakat lokal untuk bertahan hidup dalam suatu lingkungannya yang menyatu dengan sistem kepercayaan, norma, hukum, budaya, dan diekspresikan didalam tradisi dan mitos yang dianut dalam jangka waktu yang cukup lama. Adapun ciri dan fungsi dari kearifan lokal adalah sebagai berikut: penanda identitas, elemen perekat sosial, unsur budaya yang berkembang di masyarakat, memberikan warna kebersamaan bagi komunitas tertentu, mengubah pola fikir dan hubungan timbal balik individu dan kelompok, dan mendorong terbangunnya kerjasama. Oleh karena itu kebudayaan merupakan manifestasi kepribadian suatu masyarakat. ${ }^{7}$ Maharani menyebutkan bahwa Local Wisdom pada prinsipnya berangkat dari nilai-nilai asli, ekspresi- ekspresi kebudayaan asli dalam konteks geografis dan kultural dituntut untuk mampu mengekspresikan dirinya ditengah-tengah perubahan dan nilai-nilai tersebut mempunyai kemampuan untuk memegang pengendalian serta memberikan arah perkembangan kebudayaan. ${ }^{8}$

Winarto ${ }^{9}$ dalam penelitiannya menyebutkan bahwa kearifan lokal model wisata pendidikan yang berada di Brebes selatan adalah Agrowisata Kaligua Desa Pandansari, Pemandian Air Panas Desa Pakujati, Perkebunan Kentang di Desa Dawuan, Ranto Canyon di Salem, Waduk Petuguran di Desa Winduaji, Desa Santri di Benda, Home Industry Rebana di Desa Kaliwadas, Home Industry Telur Asin di Desa Karangjongkeng, Budaya Pasundan di Desa Jipang, Candi Pangkuan di Desa Cilibur. Dan hasil dari penelitiannya tentang

\footnotetext{
7 Utari, dkk. "Pembelajaran Tematik Berbasis Kearifan Lokal Di Sekolah Dasar Dalam Menghadapi Masyarakat Ekonomi Asean (MEA)” 2016

8 Maharani, "Kearifan Lokal. Ilmu Budaya dan Antropologi" 2018

9 Winarto, "Model Wisata Pendidikan Berbasis Kearifan Lokal Dengan Pendekatan Saintifik Merupakan Gagasan Konseptual Tentang Alternatif Model Pembelajaran” 2016
} 
Umi Chabibatus Zahro \& Ujang K: Pengembangan Bahan Ajar Bahasa Arab Berbasis Kearifan Lokal Brebes

"Pengembangan model wisata pendidikan berbasis kearifan lokal" menyimpulkan bahwa kearifan lokal wilayah Brebes selatan yang memiliki potensi wisata pendidikan dimanfaatkan sebagai sumber belajar yang dikemas dalam suasana belajar serta bermain sehingga model ini cocok sebagai alternatif model belajar yang sangat menyenangkan.

Penelitian terdahulu dari Utari, $\mathrm{dkk}^{1}$ kearifan lokal marhpu memfasilitasi dalam mencapai pembelajaran yang bukan hanya konseptual tetapi juga aplikatif, proses pembelajaran yang terjadi di kelas diharapkan dekat atau sering dijumpai disekitar siswa. Nilai-nilai kearifan lokal akan membantu siswa dalam memahami setiap konsep dalam materi sehingga bekal pengetahuan yang diperoleh bisa diimplemntasikan dalam wujud nyata dan memberikan pemahaman untuk bertindak tepat dalam menghadapi MEA sehingga bisa memajukan negara. Sementara Kurniawan ${ }^{1}$ dalam hasil penelitiannya tentang keefektifan bahan ajar interaktif yang berbasis kearifan lokal menyebutkan bahwa penggunaan bahan ajar yang tepat mampu memudahkan mahasiswa serta kemampuan mahasiswa meningkat karena dengan mengintegrasikan kearifan lokal dalam pembelajaran di kelas maka akan menggugah mahasiswa tentang kesadaran pentingnya kearifan lokal. Nilai-nilai luhur yang perlu dilestarikan oleh mahasiswa pada khususnya.

Integrasi kearifan local dalam bahan ajar mempunyai tujuan untuk memfasilitasi yang dapat menghubungkan antara pengetahuan mahasiswa dengan materi yang akan disajikan dalam bahan ajar bahasa Arab. Dengan kata lain, mahasiswa akan mudah memahami kosakata yang berada di lingkungannya. Kearifan lokal yang dijadikan dalam kajian bahan ajar bahasa Arab adalah 1) Agrowisata Kebun Teh Kaligua, dan 2) Tempat Pemandian Air panas.

1 Utari, dkk, "Pembelajaran Tematik Berbasis Kearifan Lokal Di Sekolah Dasar Dalam Menghadapi Masyarakat Ekonomi Asean (MEA)” 2016

1 Kurnaiawan, "Keefektifan Pehggunaan Bahan Ajar Interaktif Yang Berbasis Kearifan Lokal Brebes Dalam Mata Kulia Semantik" 2019 
Umi Chabibatus Zahro \& Ujang K: Pengembangan Bahan Ajar Bahasa Arab Berbasis Kearifan Lokal Brebes

\section{METODE PENELITIAN}

Penelitian pengembangan yang digunakan dalam penelitian ini dengan gaya Borg and Gall ${ }^{1}$, hanya saja dalam penelitian ini sampai tahapan revisi produk 1 dikarenakan situasi pandemi COVID-19. Diantara tahapannya adalah 1) analisis kebutuhan masalah yakni tahapan ini merupakan kegiatan mempersiapkan produk yang akan dikembangkan dengan melakukan studi pendahuluan untuk memperoleh informasi kebutuhan. Tahap ini meliputi studi pustaka dan wawancara seta observasi pembelajaran. 2) Perencanaan yakni tahapan ini dilakukan analisis tugas untuk menentukan isi rencana pembelajaran/materi yang akan meliputi analisis struktur isi, analisis pemetaan materi dan konsep serta analisis tujuan pembelajaran. 3) penyusunan draft bahan ajar yakni tahapan penyusunan draf produk bahan ajar yang akan digunakan dalam penelitian pengembangan ini meliputi 5 tahapan. 4) validasi produk kemudian revisi produk yang dilakukan penilaian oleh ahli materi dan teknologi pembelajaran serta media, teman sejawat, dosen, dan mahasiswa. Hasil penilaian validator digunakan untuk melakukan revisi I terhadap produk. Mahasiswa Universitas Peradaban menjadi subjek penelitian pengumpulan data. Validasi produk terdiri dari validasi materi dan validasi desain. Setelah adanya pengumpulan data maka ada analisis data yang terdiri dari observasi, wawancara, angket dan dokumentasi.

\section{HASIL DAN PEMBAHASAN}

Langkah pengembangan bahan ajar bahasa Arab berbasis kearifan lokal Brebes yang telah disusun dengan beberapa tahapan, diantaranya:

1. Analisis kebutuhan mahasiswa

Kegiatan observasi dan wawancara kepada tenaga pengajar dan mahasiswa telah dilakukan untuk menyusun bahan ajar yang dibutuhkan oleh mahasiswa Universitas Peradaban. Peneliti juga melakukan studi literatur sebagai bahan referensi penyusunan bahan ajar. Melakakukan forum group discussion (FGD) bersama mahasiswa dan tenaga pengajar untuk mengkaji data dan menyusun awal produk bahan ajar yaitu bahan ajar bahasa Arab berbasis kearifan lokal kabupaten Brebes. Di samping mahasiswa belajar dan mengungkapkan pengalamannya melalui perkuliahan bahasa Arab, mahasiswa secara tidak langsung bahwa dirinya

1 Sugiono, Metode Penelitian Pendidikan; Pendekatan Kuantitatif, Kualitatif, dan RnD. (Bandung: Alfabeta, 2010), 407 
Umi Chabibatus Zahro \& Ujang K: Pengembangan Bahan Ajar Bahasa Arab Berbasis Kearifan Lokal Brebes

mempunyai skill mempresentasikan kearifan lokal Brebes menggunakan bahasa Arab. Hasil analisis terkait minat perkuliahan bahasa Arab bis aditunjukkan pada diagram berikut ini.

Apakah anda menyukai perkuliahan bahasa Arab?

85 tanggapan
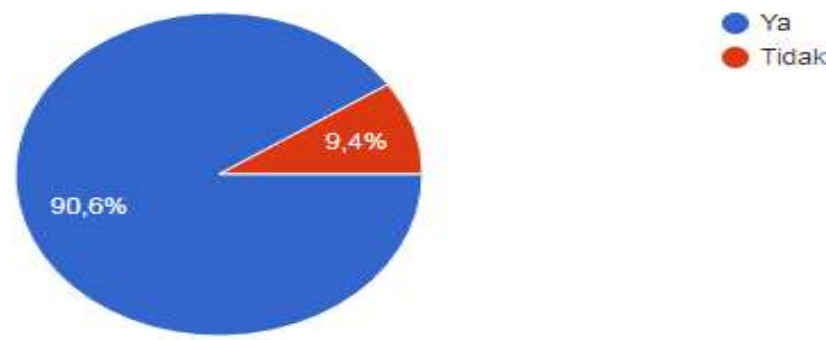

2. Perencanaan

Tahapan ini meliputi analisi struktur isi, pemetaan materi dan konsep serta analisi tujuan pembelajaran. Pada tahapan ini bahan ajar yang dikembangkan berbasis kearifan lokal kabupaten Brebes. Pada dasarnya banyak kajian kearifan lokal yang ada, diantaranya Mangrove, Waduk Malahayu, Ranto Canyon. Akan tetapi peneliti hanya mengusung maudlu' yang dikaji adalah Agrowisata Kebun Teh Kaligua dan Tempat Pemandian Air Panas di Kabupaten Brebes yaitu daerah Pakujati dan Buaran karena mempertimbangkan waktu penelitian dan sedang adanya pandemi COVID-19.

Dalam proses perencanaan ada kegiatan analisis materi kearifan lokal dan ditemukan hasil bahwa mahasiswa lebih mudah menganalisis kosakata yang disajikan dikarenakan kosakata dekat 
Umi Chabibatus Zahro \& Ujang K: Pengembangan Bahan Ajar Bahasa Arab Berbasis Kearifan Lokal Brebes

\section{Apakah materi perkuliahan bahasa Arab sulit?}

85 tanggapan

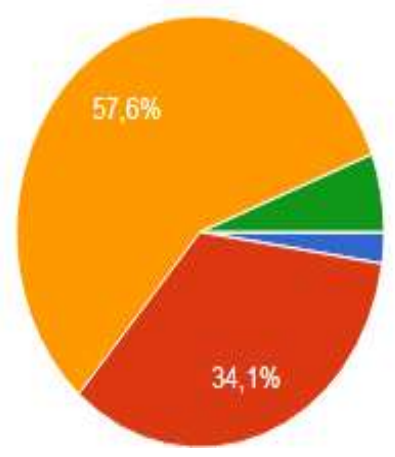

Sangat setuju

Setuju

Netral

Tidak setuju

Sangat tidak setuju

dengan mahasiswa seperti halnya materi agrowisata kaligua, cipanas pakujati dan buaran, mahasiswa 34,1\% mengatakan bahwa materi tidak sulit dikarenakan mahasiswa mempunyai pengalaman secara nyata terkait materi yang disajikan. Mahasiswa 57,6\% mengatakan bahwa materi standar, walau memang masih ada beberapa mahasiswa yang merasa kesulitan.

3. Desain produk

Desain Produk berupa bahan ajar yang dikembangkan mengikuti gaya kitab Al-arobiyah baina yadaika yang disesuiakan dengan kebutuhan mahasiswa. Tujuan peneliti disini ada beberapa, diantaranya: bahasa Arab merupakan mata kuliah wajib Universtitas sehingga perlu adanya bahan ajar yang akan digunakan dalam perkuliahan. Kabupaten Brebes mempunyai banyak kearifan lokal yang perlu dikenal oleh masyarakat dunia, dikarenakan kabupaten Brebes merupakan daerah yang komplit, maksudnya dari mulai pantai, pegunungan, hutan, semunya ada di daerah Brebes. Beberapa teks yang ada dalam bahan ajar. 
Umi Chabibatus Zahro \& Ujang K: Pengembangan Bahan Ajar Bahasa Arab Berbasis Kearifan Lokal Brebes

\section{الوحدة الثانية : مكان السياحة (كالي جووا)}
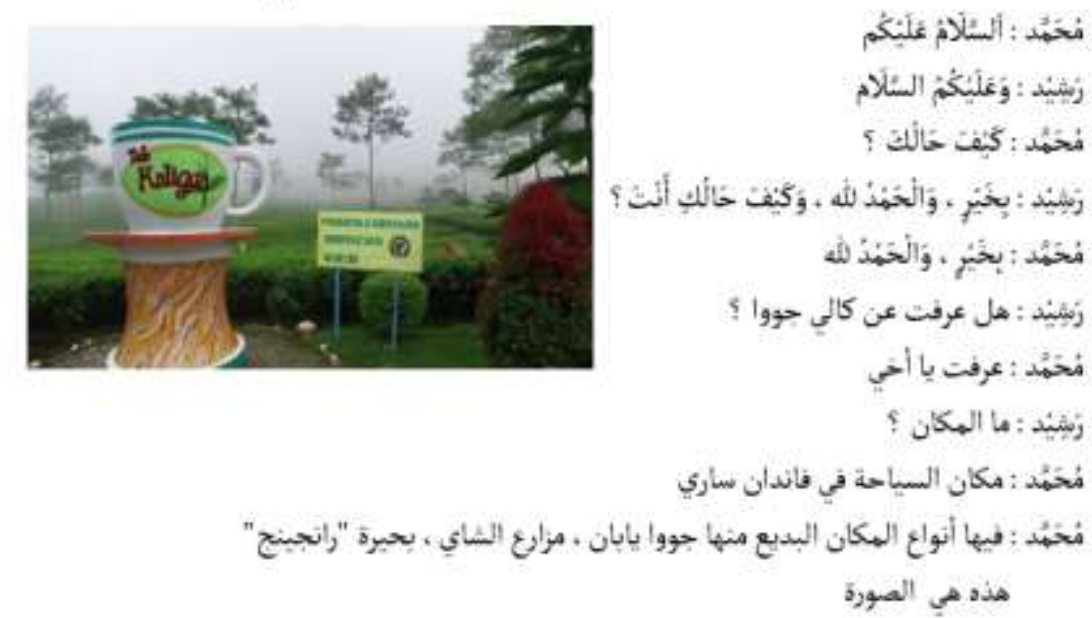

الوحدة الثالثة : مكان الحميمة "بوواران" و "فاكو جاتي"

$$
\begin{aligned}
& \text { أحمد : الَسَّلَامُ عَلَنْكم } \\
& \text { غزالي : وَعَلَيْكُمُم السَّلَام }
\end{aligned}
$$

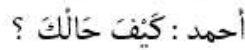

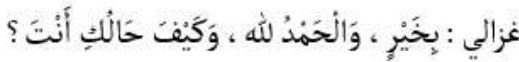

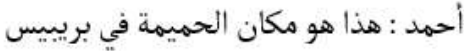
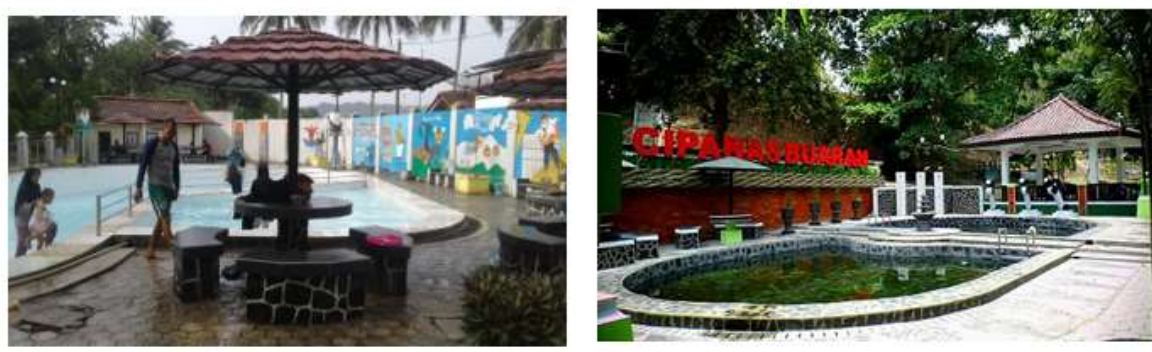

4. Validasi Desain

Validasi desain dilakukan oleh para ahli, yaitu ahli materi dan ahli desain dengan mengunakan angket sebagai instrumennya. Hasil dari dua validator menyatakan sebesar 78,8 dan 78,5 dengan kategori cukup valid, dapat digunakan namun perlu revisi. Meskipun materi 
Umi Chabibatus Zahro \& Ujang K: Pengembangan Bahan Ajar Bahasa Arab Berbasis Kearifan Lokal Brebes

sudah sesuai dan baik yaitu kearifan lokal kabupaten Brebes. Berikut hasil validasi ahli

Diagram 1. Penilaian validator

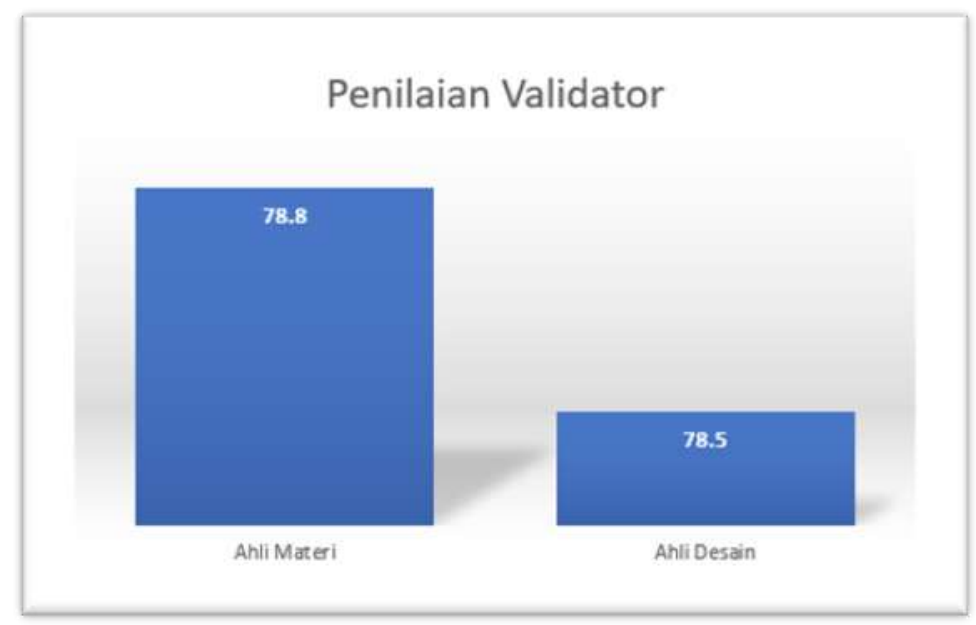

Keterangan kriteria deskriptif:

\begin{tabular}{|r|l|}
\hline Kriteria Validitas & \multicolumn{1}{|c|}{ Tingkat Validitas } \\
\hline $81,0 \%-100,0 \%$ & Sangat valid, dapat digunakan tanpa revisi \\
\hline $\mathbf{6 1 , 0} \%-\mathbf{8 0 , 9} \%$ & $\begin{array}{l}\text { Cukup valid, dapat digunakan namun perlu } \\
\text { revisi }\end{array}$ \\
\hline $41,0 \%-60,9 \%$ & $\begin{array}{l}\text { Kurang valid, disarankan tidak digunakan karena } \\
\text { perlu } \\
\text { revisi besar }\end{array}$ \\
\hline $21,0 \%-40,9 \%$ & Tidak valid, tidak boleh dipergunakan \\
\hline
\end{tabular}

5. Revisi Desain

Beberapa saran dan masukan dari validator, termasuk di dalamnya adalah tata letak dan bahasa sudah direvisi oleh peneliti.

Dari hasil penelitian itu dapat dikaitkan dengan penelitian yang sudah ada terkait dengan bahan ajar yang dikembangkan yakni punya Novi dan Siti ${ }^{1}$ dalam jurnal pendidikan karakter No 1 tahun 2017 yang berjudul pengembangan bahan ajar tematik-integratif berbasis kearifan lokal untuk meningkatkan karakter peduli dan tanggung jawab menyebutkan bahwa

1 Novi dan Siti, "Pengembangān Bahan Ajar Tematik-Integratif Berbasis Kearifan Lokal Untuk Meningkatkan Karakter Peduli Dan Tanggung Jawab” 2017 
Umi Chabibatus Zahro \& Ujang K: Pengembangan Bahan Ajar Bahasa Arab Berbasis Kearifan Lokal Brebes

bahan ajar yang dikembangkan layak untuk digunakan.

Sejalan dengan Hasil Penelitian Zukhaira dkk ${ }^{1}$ dalam jurnal penelitian pendidikan vol. 3 No. 1 yang berjudul Desain Pengembangan Buku Ajar bahasa Arab berbasis pendidikan karakter dan budaya kelas Adan B TK Islam bahwa standar kompetensi, kompetensi dasar dan indikator pencapaian kompetensi yang dibuat telah disesuaikan dengan materi tematik yang tertera pada peraturan pemerintah No. 58 tahun 2009 dan disesuaikan dengan Menteri Pendidikan nasional berbasis karakter dan budaya. Keefektifan buku ajar sudah diuji dengan hasil 18,33\% menilai sangat baik, 56,67\% menilai baik dan 25\% menilai cukup (Zukhaira \& Hasyim, 2013).

\section{SIMPULAN}

Berdasarkan hasil pengembangan bahan ajar bahasa Arab berbasis kearifan lokal kabupaten Brebes yang mengusung maudlu agrowisata kebun teh kaligua dan tempat pemandian air panas di daerah Pakujati dan Buaran sudah pada sampai tahapan revisi produk 1. Tahapan pertama, analisis kebutuhan mahasiswa. Kedua, data kebutuhan mahasiswa digunakan untuk menyusun konsep bahan ajar. Ketiga, merancang produk bahan ajar termasuk di dalamnya pemilihan karakterisitik bahan ajar. Keempat, penilaian hasil rancangan oleh para ahli, diantaranya materi dan desain. Kelima, revisi produk sesuai dengan saran dan masukan oleh ahli media dan desain. Dengan hasil penilaian validator sebesar 78,8 dan 78,5 kriteria cukup valid, dapat digunakan namun perlu revisi.

\section{DAFTAR PUSTAKA}

Al-Fauzan, Abd ar-Rahman bin Ibrohim, dkk. Al-Arobiyah Baina Yadaika. Saudi Arabia: Muassah al-waqf al-Islami. 2003

Arsyad, Azhar. Bahasa Arab dan Metode Pengajarannya. Yogyakarta: Pustaka Pelajar. 2004.

Asrori, Imam, dkk. Evaluasi Pembelajaran Bahasa Arab. Malang: Misykat. 2012 Depdikbud. Kamus Besar Bahasa Indonesia. Jakarta: Depdikbud. 2002.

Effendy, Ahmad Fuad. Metodologi Pengajaran Bahasa Arab. Malang: Misykat. 2012

1 Zukhaira, "Desain Pengembangan Buku Ajar Bahasa Arab Berbasis Pendidikan Karakter Dan Budaya Kelas A Dan B Tk Islam” 2013 
Umi Chabibatus Zahro \& Ujang K: Pengembangan Bahan Ajar Bahasa Arab Berbasis Kearifan Lokal Brebes

Gholayaini, Mustafa. Jami' Durus Al-Arobiyah. Beirut: Maktabah Asyriah. 1994 Lestari, Ika. Pengembangan Bahan Ajar Berbasis Kompetensi. Padang: Akademia. 2013.

Maharani, Rheva. Kearifan Lokal. Ilmu Budaya dan Antropologi. Retrieved from: https://www.dictio.id/t/apa-yang-dimaksud-dengan-kearifanlokal/116564. 2018.

Sitepu. Penulisan Buku Teks Pelajaran. Bandung: Remaja Rosdakarya. 2012. Kurniawan, P. Y. (2019). Keefektifan Penggunaan Bahan Ajar Interaktif Yang Berbasis Kearifan Lokal Brebes Dalam Mata Kulia Semantik. BAHASTRA Jurnal Pendidikan Bahasa Dan Sastra Indonesia ISSN: 2550-0848; ISSN Online: 2614-2988 Vol. 3, No. 2, Maret 2019, 3(2), 170-176. https://jurnal.uisu.ac.id/index.php/Bahastra/article/view/3167/2110

Lestariningsih, N., \& Suardiman, S. P. (2017). Pengembangan Bahan Ajar Tematik-Integratif Berbasis Kearifan Lokal Untuk Meningkatkan Karakter Peduli Dan Tanggung Jawab. Jurnal Pendidikan Karakter, 7(1). https://doi.org/10.21831/jpk.v7i1.15503

Utari, U., Degeng, I. N. S., \& Akbar, S. (2016). Pembelajaran Tematik Berbasis Kearifan Lokal Di Sekolah Dasar Dalam Menghadapi Masyarakat Ekonomi Asean (MEA). Jurnal Teori Dan Praksis Pembelajaran IPS, 1(1), 39-44. https://doi.org/10.17977/um022v1i12016p039

Winarto. (2016). Model wisata pendidikan berbasis kearifan lokal dengan pendekatan saintifik merupakan gagasan konseptual tentang alternatif model pembelajaran yang berfokus pada. Jurnal Dialektika Jurusan Pgsd, 6(2), 32-48

https://journal.peradaban.ac.id/index.php/jdpgsd/article/view/6/4

Zukhaira, Z., \& Hasyim, M. (2013). Desain Pengembangan Buku Ajar Bahasa Arab Berbasis Pendidikan Karakter Dan Budaya Kelas A Dan B Tk Islam. Jurnal Penelitian Pendidikan Unnes, 30(1), 125506. https://doi.org/10.15294/jpp.v30i1.5669

Sugiono. Statistika untuk Penelitian. Bandung: Alfabeta. 2012.

--------. Metode Penelitian Pendidikan; Pendekatan Kuantitatif, Kualitatif, dan RnD. Bandung: Alfabeta. 2010.

Sumarmi \& Amiruddin. Pengelolaan Lingkungan Berbasis Kearifan Lokal. Yogyakarta: Aditya Medai Publishing. 2014.

Nurul Isnaini, Nurul Huda. Pengembangan Media Pembelajaran Kosakata Bahasa Arab Berbasis Permainan My Happy Route. Jurnal Al Mi'yar Vol.3 No.1 April 2020. 